\title{
Deramatophilosis in Draught and Dairy Cattle in Tamil Nadu Delta Districts of India
}

\author{
S Krishna Kumar ${ }^{*}$, S Kavitha ${ }^{2}$, P Selvaraj ${ }^{1}$, R Sivakumar ${ }^{1}$, M Ranjith Kumar ${ }^{3}$ and S Yogeshpriya ${ }^{1}$ \\ ${ }^{1}$ Department of Veterinary Medicine, Veterinary College and Research Institute, India \\ ${ }^{2}$ The Professor and Head, Peripheral Veterinary Hospital, India \\ ${ }^{3}$ Department of Veterinary clinical medicine, Madras Veterinary College, India
}

Submission: March 09, 2018; Published: April 26, 2018

"Corresponding author: S Krishna Kumar, Assistant Professor, Department of Veterinary Medicine, Veterinary College and Research Institute, Orathanadu, Thanjavur- 614 625, Tamil Nadu, India, Email: subbiahkrishnakumar74@gmail.com

\begin{abstract}
Chronic dermatitis caused by Dermatophilosis in dairy and drought animals were studied in delta districts of Tamilnadu. Dermatophilosis is a contagious zoonotic skin disease caused by Dermatophilus congolensis with wide host range and most commonly affects cattle, sheep and horse. The disease is characterized by exudative dermatitis with scab formation. Factors such as prolonged wetting by rain, high humidity, high temperature, mechanical injury to the skin, concurrent disease, stress and tick infestation that reduce or permeate the natural barrier of the integument influence the development, prevalence, seasonal incidence and transmission of Dermatophilosis. A cross sectional study on prevalence of Deramtophilosis was carried out and epidemiologic risk factors like age, breed, sex and seasonal coditions were corelated with the prevalence of Dermatophilosis. This study concludes that winter season, higher age group, female and jersey cross bred will be the risk factors for Dermatophilosis prevalence and oxytetracycline is the chioce of antibiotic for clinical management.
\end{abstract}

\section{Introduction}

Agrarian economy of the detal districts of Tamilnadu remain heavily depended on draught cattle and livestock. Dairy animals remain bread winners for the agriculture labours and the landless people. The economic value of these cattle were observed to be subvalued due to the presense of damaging lesions in the skin due to Dermatophilosis (also known as Streptothrichosis). Dermatophilosis caused by the bacterium Dermatophilus congolensis, is an exudative, pustular dermatitis that mainly affects cattle, sheep and horses, but also goats, dogs and cats, many wild mammals, reptiles occasionally, humans also affected [1]. The clinical picture includes matting of the hair or wool, scab and crust formation and generalized massive crust formation in chronic cases which leads to loss of hair and even local loss of the upper skin layers predisposing to secondary infections. Several factors like mechanical injury to the skin, rainfall, tick infestation, concurrent diseases and stress are involved in the pathogenesis of Dermatophilosis and claimed to be a major predisposing factor in the epidemiology of Dermatophilosis [2]. Moisture facilitates release of zoospores from preexisting lesions and theiy Results subsequently penetrates the epidermis and establishments new infection [3]. Diagnosis made based on clinical appearance of the lesion and demonstrating the causal organism from the lesions beneath the scabs [4]. Confirmatory diagnosis of the disease may be achieved by culturing and identification of the pathogen on blood agar bacteriological media.

\section{Materials and Methods}

The study area covered the delta regions of Tamilnadu with the Thanjavur district as the main target. Clinical samples of dermatological lesions were collected with epidemiological data and subjected to laboratory examinations. The distribution of lesions on affected animals were recorded. The selected samples were processed for identification of Dermatophilosis.

Supected skin samples of affected area were collected and placed in the petridishes with normal slaine for over night. Deep impression smear was collected form the soaked materials [5]. The smears were stainined with Giemsa staining and susequently confirmed in Sheep blood agar [6].

Table 1: Epidemiological profile of Dermatophilosis in delta region of Tamil Nadu.

\begin{tabular}{|c|c|c|}
\hline Risk factors & Category & Total number of cases (\%) \\
\hline \multirow{3}{*}{ Total number of bovine dermatology cases } & Dermatophilosis & $19.40(21 / 108)$ \\
\cline { 2 - 3 } & Mange & $3.70(04 / 108)$ \\
\cline { 2 - 3 } & Fungal dermatitis & $4.62(03 / 108)$ \\
\hline
\end{tabular}


Annals of Reviews and Research

\begin{tabular}{|c|c|c|}
\hline \multicolumn{2}{|c|}{ Risk factors for Dermatophilosis } \\
\hline \multirow{2}{*}{ Seasonal Profile } & Winter & $71.50(15 / 21)$ \\
\cline { 2 - 3 } & Summer & $28.50(06 / 21)$ \\
\hline \multirow{3}{*}{ Age Profile } & $>2$ years & $28.5(06 / 21)$ \\
\cline { 2 - 3 } & $2-5$ years & $52.30(11 / 21)$ \\
\cline { 2 - 3 } & $<5$ years & $80.90(17 / 21)$ \\
\hline \multirow{2}{*}{ Breed Profile } & Jersey cross & $19.10(04 / 21)$ \\
\hline \multirow{2}{*}{ Sex Profile } & Holstein Friesian cross & $9.50(02 / 21)$ \\
\hline
\end{tabular}

Detal districts of Tamilnadu has recorded with higer prevalnce of Dermatophilosis in dairy cattle. A sum of 108 cattle were screened for various dermatological disorders and 28 cases were found to be afflected with Dermatophilosis (Table 1). Winter season $(71.5 \%)$ had a higher prevalence than the summer (28.5\%). All age groups in both male and females were affected. Higher age group ( $<5$ years) showed $52.3 \%$ morbidity than younger age group. Females were found to have a higher rate $(90.5 \%)$ of infection than male $(9.5 \%)$.

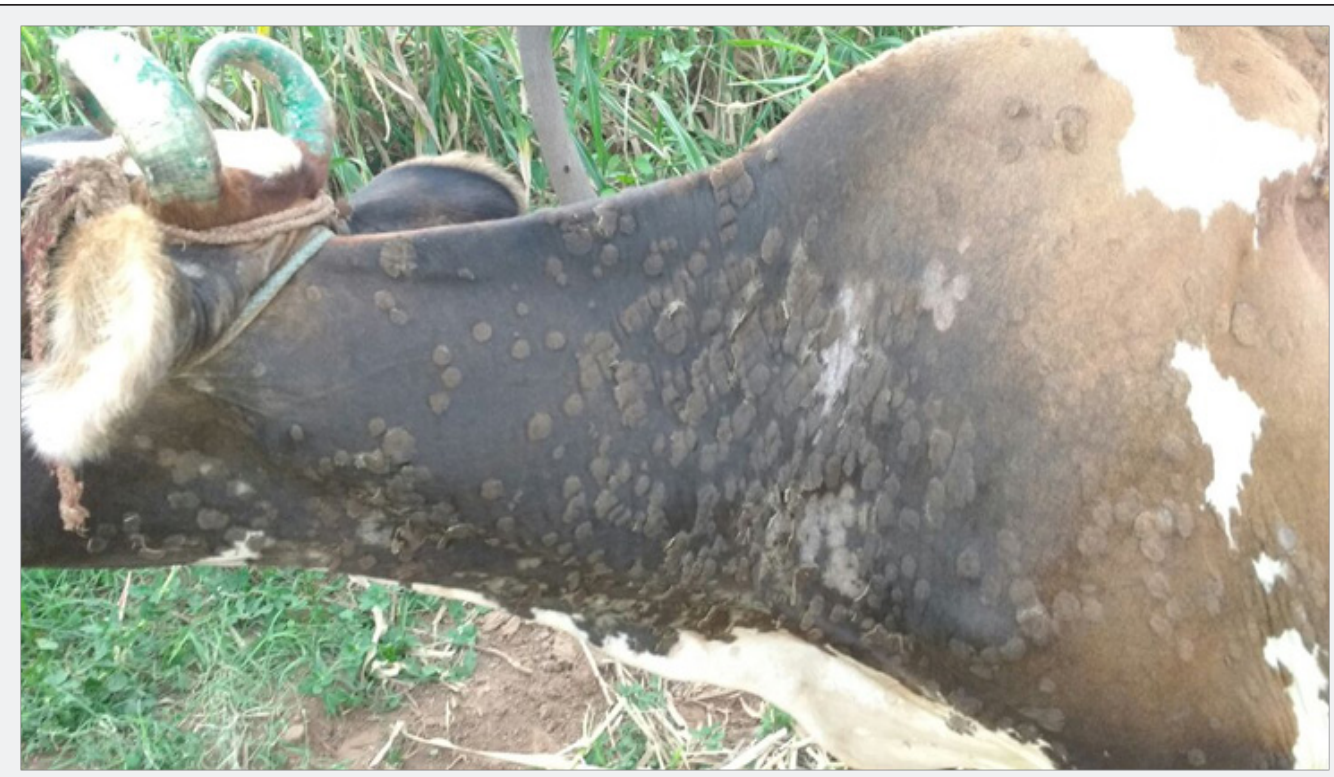

Figure 1: Skin scabs in Dermatophilosis affected crossbred cattle.

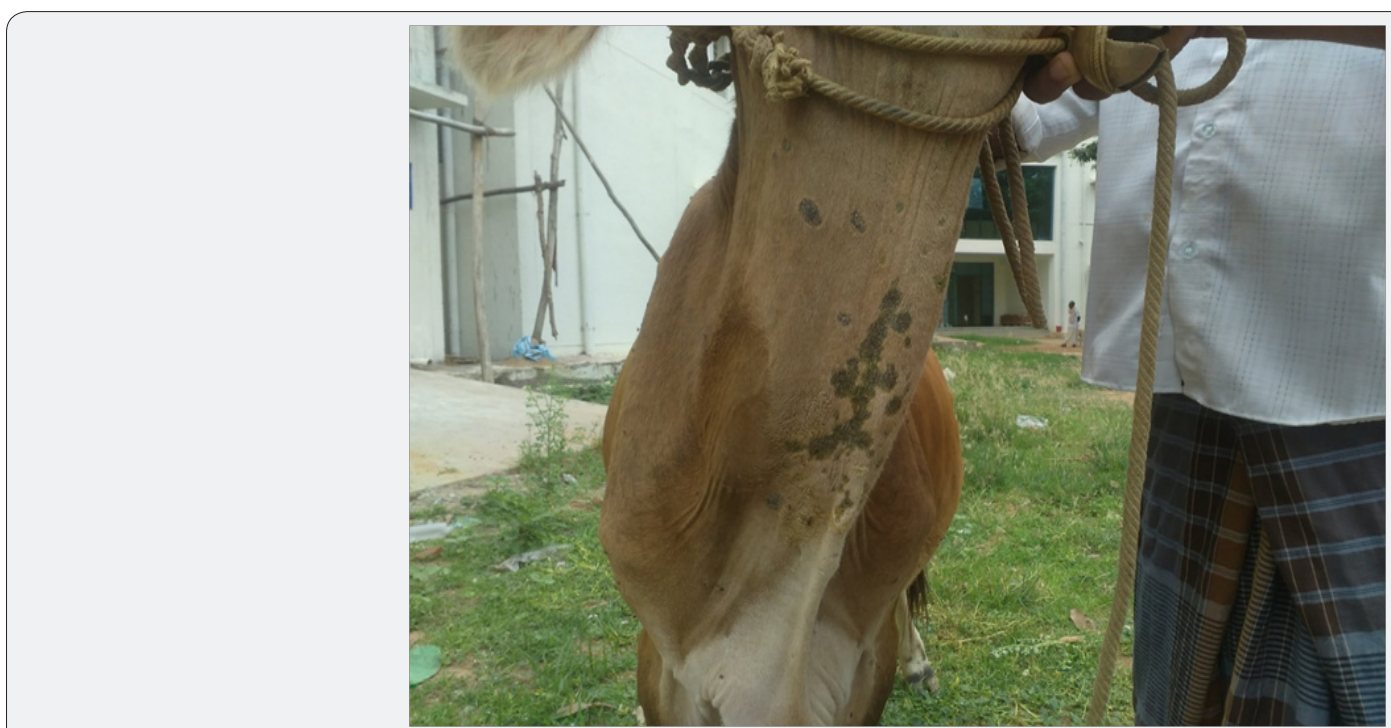

Figure 2: Exudative dermatitis in Dermatophilosis affected crossbred cattle 


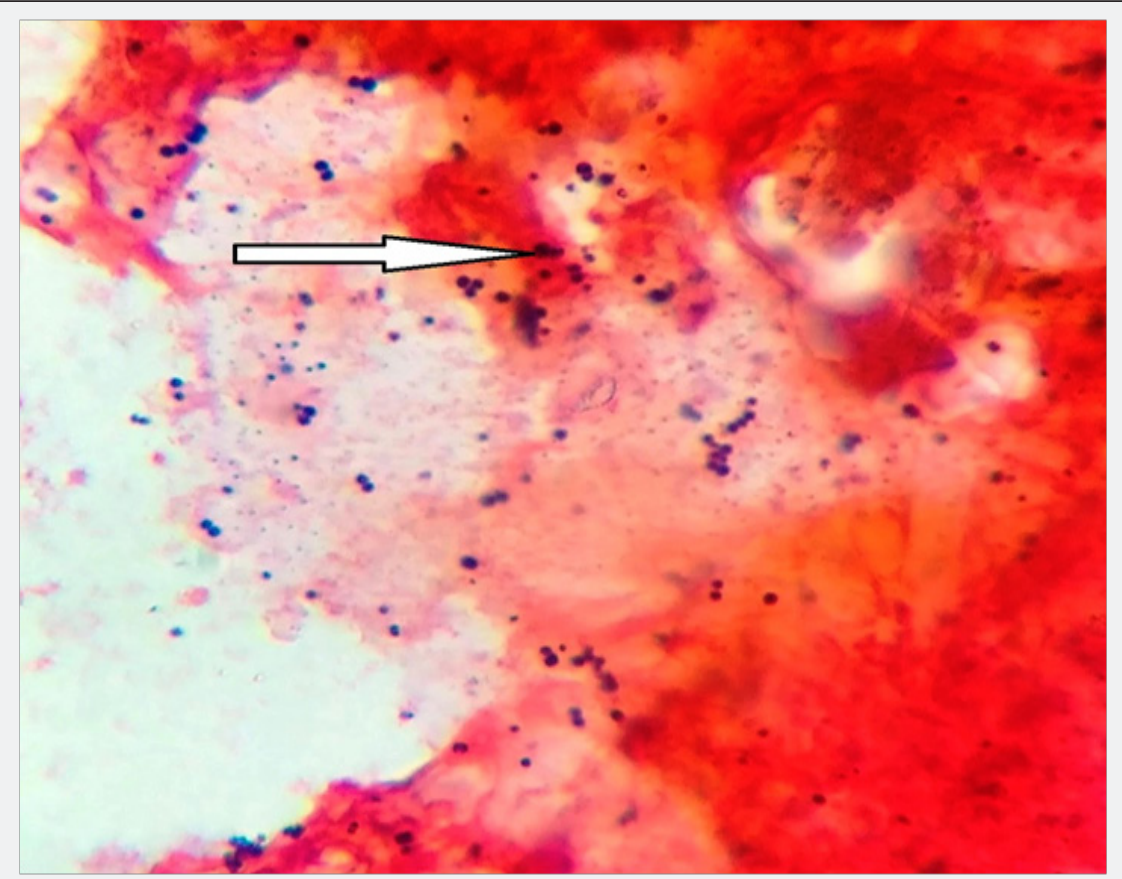

Figure 3: Dermatiphilus congolensis in skin samples stained with Grams staining.



Figure 4: Beta hemolysis of Dermatophilus congolensis in Sheep blood agar.

Out of 21 dermatiphilosis posititve animals 17 (80.9\%) were Jersey crossbred cows and (19.1\%) were Holsteinfresian crossbred. Typically clinical presentation included the formation of dense scabs on the skin (Figure 1) especially moist lesions with thickened, folded skin in areas like neck, udder and perineum was observed. After a time gap, dry scab peeled off and dry/wet exudative lesions were seen (Figure 2). Severe itching, hair loss, reduction in milk production was common among dairy animals. The processed samples were shown gram positive cocci in a specified manner was noticed (Figure 3). The strains of Dermatophilus congolensis grew on blood agar with washed sheep erythrocytes with marked total hemolysis and gave a significant synergistic effect of a characteristic shape (Figure 4).

\section{Discussion}

This reaearch work targets the dairy cow and drought animals to ascertain the prevalence of dermatophilosis in delta region.Clinical samples like dry scab and wet impression smear were coleected and sujected to bacteriological examination. Higher incidence of dermatophilosis recorded during winter because of prolonged wetting makes break in the skin to establish the infection and multiplication of the organism in the epidermis and concomitant increase in tick and insect infestation [5]. Humidity, high ambient temperature, ectoparasites, carrier animals, malnutrition, intense rainfalls and mechanical traumas are important factors which was recorded by Andrew AH [7]. All theses factors are more prevalent in delta districts of Tamil Nadu, 
particularly in Thanjavur. During the monsoon season, water flow in the irrigation canals augments the disease prevalence, as majority of these cases were obsereved during such times. Dairy and draught cattle of Thanjavur districts were observed to have an epidemic pattern of skin lesions particularly during rainy seasons and during the periods where in heavy water flow is present in irrigation channels across agricultural fields.

These bacteria are usually found under the skin surfaces and under favorable environmental risk factors like relative humidity and rain fall, these organism grow well and produce clinical disease. Ecologically Thanjavur, Nagapattinam and Tiruvarur delta districts of Tamil Nadu are located in sea shore area and have high humidity thought the year. These districts also experiences abnormal rain fall during monsoon seasons [8]. Because of the prevalent community or group grazing pattern, practised by livestock keepers in these areas it paves way for easy transmission to other animals. Eventhough some of the animals showed self limiting pattern, most of the animals had anorexia, loss of milk yield and poor skin and coat.Eventhough most of the researchers found tick infestation along with Dermatophilosis [3] but this study was not witnessed with tick infestation.

Most of the skin lesions were seen on the rump and back in dairy cows and drought animals probably due to the introduction of infection through minor skin abrasions caused by mounting, other penetrating lesions caused by yolk respectively. Typical clinical symptoms in this study consists of circular, dome shaped scab about $3-9 \mathrm{~cm}$ in diameter may be due to yellowish exudates, leaving a row, bleeding epidermis and normal skin surface has been disrupted and activated zoospores gain access to the epidermis, infection can develop and the zoospores are apparently attracted to the low carbon dioxide [6]. Pin point colonies surrounded by small zones beta hemolysis are evident after twenty four hour incubation at $370 \mathrm{C}$ was noiced as noticed [2].

Dermatiphilosis cases were successfully treated with Oxytetracycline with parental Oxytetracycline / Streptopeneicillin at standard doses with external application of sulphur ointment and feed supplements had helped in better recovery from the disease as recommended by Susan EA [5].

Prevention and control of dermatophilosis is by isolation and treatment of affected animals, maintaining good plan of nutrition with mineral supplementations and avoiding community / group grazing practices.

\section{References}

1. Dalis SJ, Kazzem HM, Makinde AA, Fatihu MY (2010) Bacteria associated with Bovine Dermatophilosis in Zaria, Nigeria. Africa Journal of Microbiology 4(14): 1475-1479.

2. Yeruham I, Hadani A, Eiad D, Ratner D, Peri SH, et al. (1991) Dermatophilosis (Dermatophilus congolensis) Accompanied by Contagious Ecthyma (On) in a Flock of Yaez in Israel. lsr J Vet Med 46: 74-78.

3. Radostits OM, Gray CG, Hinchcliff Constable KW (2007) Veterinary Medicine, A Text Book of the Disease of Cattle, Horses, Sheep, Pigs, and Goats. (10 $\left.{ }^{\text {th }} \mathrm{edn}\right)$, Saunders Elsevier, London, pp. 1048-1051.

4. Kahn CM (2005) The Merck Veterinary Manual. ( $9^{\text {th }}$ edn), Merck and Co. Inc, USA, pp. 690-691.

5. Susan EA (2009) Dermatophilosis in cattle. Veterinary Merck manual, (10 ${ }^{\text {th }}$ edn), pp. 328-329.

6. OIE (2008) Dermatophilosis Terrestrial manual, pp. 725-727.

7. Andrew AH, Blawey RW, Boyd H, Eddy RG(2003) Bovine Medicine, Disease and Husbandry of Cattle. ( $2^{\text {nd }}$ edn), Black Well Science, UK, pp. 886-887.

8. Jubb FVK, Kennedy CP, Palmel N (1992) Pathology of Domestic Animals. ( $4^{\text {th }}$ edn), Acadamic Press Limited, UK, pp. 648-650.

\begin{tabular}{|l|}
\hline \multicolumn{1}{|c|}{ Your next submission with Juniper Publishers } \\
will reach you the below assets \\
- Quality Editorial service \\
- Swift Peer Review \\
- Reprints availability \\
- E-prints Service \\
- Manuscript Podcast for convenient understanding \\
- Global attainment for your research \\
- Manuscript accessibility in different formats \\
( Pdf, E-pub, Full Text, Audio) \\
- Unceasing customer service \\
Track the below URL for one-step submission \\
https://juniperpublishers.com/online-submission.php \\
\hline
\end{tabular}

